\title{
UNDERSTANDING THE DISPARITY IN AVAILABILITY OF PRESCRIPTION DRUGS IN THE UNITED STATES: COMPROMISE MAY BE THE ANSWER
}

\author{
Natalie J. Tanner
}

\section{INTRODUCTION}

The issue of pharmaceutical drug affordability has moved to the forefront of political and public health concerns over the past decade. The increasing prices of prescription drugs in the United States have denied a class of people access to medication. This problem is not limited to the United States; similar and often more acute dilemmas can be seen in many developing countries.

The high prices of pharmaceuticals in the United States can be attributed to several factors. The two most prevalent are the temporary monopolies large pharmaceutical companies gain upon receiving patents for their products, and the stringent standards which those drugs must meet under Food and Drug Administration (FDA) regulation. ${ }^{1}$ The monopolies granted to the patenting companies are not without justification because those companies must invest millions of dollars in research and development (R\&D) of these new drugs. ${ }^{2}$ The patent monopolies act to fulfill the companies' investment-backed

* J.D. Candidate, 2005, Indiana University School of Law-Indianapolis; B.S. in Biomedical Science, 2002, Texas A\&M University, College Station, Texas. I would like to give a special thanks to my family, Professor William Bradford, and Professor Richard Wright for all of their much appreciated advice and support.

1. See Mark B. McClellan, Commissioner, Food \& Drug Administration, Speech at the Fifth Annual David A. Winston Lecture (Oct. 20, 2003) [hereinafter McClellan FDA Speech], available at $\mathrm{http} / / \mathrm{www} . \mathrm{fda} . g o v / o c /$ speeches/2003/winston1020.html.

2. See Michele L. Creech, Comment, Make a Run for the Border: Why the United States Government is Looking to the International Market for Affordable Prescription Drugs, 15 EMORY INT'L L. REV. 593, 600-04 (2001) (indicating that patents are granted to originator products to allow developers to recoup R\&D expenses); see also Robert Lenzner, The Effects Could Be Devastating, FORBES, Nov. 27, 2000, at 156. But cf. Lawrence A. Sullivan, Antitrust: New Economy, New Regime Second Annual Symposium of the American Antitrust Institute: Is Competition Policy Possible in High Tech Markets?: An Inquiry Into Antitrust, Intellectual Property and Broadband Regulation as Applied to "The New Economy," 52 CASE W. RES. L. REV. 41, 63 (2001) (arguing that R\&D grants cannot continue to rise per company without an accompanying oppressive effect on competition in that market). See generally PHARMACEUTICAL RESEARCH \& MFG. OF AM., Why DO PRESCRIPTION DRUGS COST SO MUCH? ... AND OTHER QUESTIONS ABOUT YOUR MEDICINES (2000) [hereinafter QUESTIONS ABOUT MEDICINES] (explaining the different factors affecting the rising costs of pharmaceutical drugs), available at $\mathrm{http} / / \mathrm{www}$.phrma.org/publications/publications/brochure/questions/questions.pdf. 
expectations and create incentives for the companies to continue their costly research in pursuit of new and improved pharmaceuticals. ${ }^{3}$

The general rule of law is that patents do not extend extraterritorially; therefore, countries around the world have the capability to set up their own patent requirements. ${ }^{4}$ This creates divergent international standards, which breed, among other difficulties, many patent infringement issues. This is especially relevant to large pharmaceutical companies with global markets. ${ }^{5}$

In addition to the differing patent standards among countries, the intangible nature of patent rights makes them especially difficult to protect from infringement. ${ }^{6}$ While large amounts of time and money must be devoted towards developing the initial chemical structure of a drug, once it has been determined, it is much easier and less expensive to produce the actual drug product. ${ }^{7}$ Anyone who did not invest their resources in the costly research and development process could easily replicate that chemical structure through inexpensive methods, such as reverse engineering, bypassing all of the necessary R\&D costs. ${ }^{8}$

In the United States, the high cost of pharmaceutical drugs has led to an increasing number of people turning to foreign pharmaceutical manufacturers, commonly in Mexico and Canada, where cheaper, generic versions of the medication they need are available. ${ }^{9}$ The manufacturers in these foreign companies are able to sell these drugs cheaper than the United States companies because they do not have the R\&D overhead to recoup. ${ }^{10}$ These drugs are also

3. Creech, supra note 2, at 600; see also Christopher Scott Harrison, Comment, Protection of Pharmaceuticals as Foreign Policy: The Canada-United States Trade Agreement and Bill C-22 Versus the North American Free Trade Agreement and Bill C-91, 26 N.C. J. INT'L L. \& COM. REG. 457 (2001). But cf. Sullivan, supra note 2, at 63 (asserting competition will eventually be suppressed if $R \& D$ grants continue to grow per company).

4. Paper Converting Mach. Co. v. Magna-Graphics Corp., 745 F.2d 11, 17 (Fed. Cir. 1984).

5. Harrison, supra note 3, at 466-67.

6. Id. at 463 .

7. Id. at 494 .

8. Id. at 493-94.

9. McClellan FDA Speech, supra note 1; Robert Pear, Lawmakers Are Negotiating Import of Prescription Drugs, N.Y. TnMES, Oct. 31, 2003, at A14. The internet has greatly increased the American consumer's ability to reach foreign pharmaceutical manufacturers. While this note acknowledges that prescription and non-prescription drugs are imported into the United States from all over the world, the scope of this note will focus mainly on prescription drugs from Canada. In addition, any reference made to "foreign pharmaceuticals" or "foreign drugs" also includes American-made drugs sold in Canada by the authorized patent holder and subsequently re-imported into the United States, unless otherwise specified.

10. See Bruce A Lehman, Intellectual Property Under the Clinton Administration, 27

GEO. WASH. J. INT'L. L. \& ECON. 395, 395 (1994) ("Other nations often look for a free ride, seeking to build their economies not by encouraging the innovation and creativity of their own people through strong protection for all forms of intellectual property, but by promoting intellectual property piracy through weak laws or no protection at all."). 
less regulated, ${ }^{11}$ and some can be purchased without a prescription. ${ }^{12}$ In addition to these safety issues, their use in the United States presents a question as to patent infringement.

The escalating prices of pharmaceuticals in the United States have created an incentive for state governments to seek and even subsidize foreign pharmaceutical companies in order to provide lower priced pharmaceuticals to United States citizens who cannot afford the high prices in the United States. This creates several legal questions concerning whether a state, or even the federal government, could subsidize these foreign companies without violating existing United States law. This question consists of several issues, including whether this should be considered either a patent infringement under the United States Patent Code or a "taking" under the Fifth Amendment of the United States Constitution. Moreover, if such governmental subsidies of foreign drug makers are considered an infringement or a taking, the law is not clear as to how or by whom the patent-holding companies should be compensated. This is a novel issue and has not yet been ruled upon by the United States Supreme Court. This Note will focus on the different interests associated with the increasing problem of high cost pharmaceuticals and propose a resolution based on the notion of compromise.

Pharmaceutical pricing in the United States is a complex topic and one in which numerous parties have considerable interests involved. In addition, each of these groups influences the situation in their own individual way. Parts I, II, and III of this Note will assess the problem-who the affected parties are, the pharmaceutical industry's justification for their high prices, and the gravity of the situation that has evolved. Secondly, this Note will provide an overview of the evolution of Canadian patent law and the importation of Canadian drugs into the United States. Part V then evaluates the United States law applicable to the pharmaceutical drug importation issue. The conclusion outlines the proposals for action at the federal level, which entail a comprehensive structuring of a new system aimed solely at the prescription drug industry.

11. Gardiner Harris \& Monica Davey, U.S. Steps Up Effort Against Drug Imports, N.Y. Times, Jan. 24, 2004, at C1; Bernard Simon, Canada Resists U.S. Pressure on Drug Sales, N.Y. TIMES, Nov. 20, 2003, at C9.

12. William K. Hubbard, Senior Associate Commissioner for Policy, Planning and Legislation, Food \& Drug Administration. Statement before the Subcom. on Health, Comm. on Energy \& Commerce (July 25, 2002), available at http://www.fda.gov/ola/2002/ drugimportation0725.html; BLANCHARD RANDALL IV \& DONNA U. VOGT, CONG. RES. SERV., IMPORTING PRESCRIPTION DRUGS CRS-2 (Aug. 22, 2002), available at http://www.law .umaryland.edu/marshall/ElectornicResources/crsreports/crsdocuments/ RL31503.pdf. 


\section{PARTIES AFFECTED By THE INCREASED PRICES OF PHARMACEUTICAL DRUGS}

\section{A. The Elderly, Impoverished, and Uninsured}

While American pharmaceutical consumers in general pay more for prescription drugs than citizens in other developed countries, ${ }^{13}$ the United States' elderly and uninsured bear the heaviest burdens. The problem of affordability has become exceptionally severe for older people who are unable to manage their finances when they become ill. ${ }^{14}$ While prescription drugs represent a relatively small part of total consumer household spending on average,$^{15}$ this amount increases significantly with age. ${ }^{16}$ Several factors are responsible for this trend, for instance, that the elderly are living longer ${ }^{17}$ and sixty-five to seventy-five year old demographic has a low median income. ${ }^{18}$

The poor are an additional class faced with the predicament of pharmaceutical drug affordability. In 1999, approximately 42.6 million people in the United States had no health insurance coverage whatsoever. ${ }^{19}$ Without health insurance coverage, consumers are forced to pay for prescription drugs out-of-pocket, a next to impossible feat for many..$^{20}$ A 2001 survey revealed that noncompliance with prescribed medication in order to save money is much higher with people in low income groups. ${ }^{21}$ Thus, when faced with the

13. Merrill Goozner, The Price Isn't Right, AM. ProsPECT, Sept. 11, 2000, at 25.

14. Broderick Perkins, High Cost of Pharmaceutical, DEADLINENEws.COM, Mar. 22, 2002, at http://www.deadlinenews.com/drugcosts32902.html (last visited Apr. 17, 2005) (on file with the Indiana Health Law Review).

15. KAISER FAMILY FOUNDATION, PRESCRIPTION DRUG TREND-A CHARTBOOK UPDATE 25, ex. 11 (Nov. 2001), available at http://www.kff.org/rxdrugs/loader.cfm?url=/commonspot/ security/getfile.cfm\&PageID=13796.

16. BUREAU OF LABOR STATISTICS, U.S. DEP'T OF LABOR, CONSUMER EXPENDITURE SURVEY tbl. 47 (2002), available at http://www.bls.gov/cex/2002/share/age.pdf. In 2002, the average consumer spending on drugs was $1.2 \%$ of their annual expenditures. Id. However, individuals sixty-five and above spent $3.4 \%$ of their annual consumer expenditures on drugs, while the seventy-five years plus demographic increased their drug expenditures even more to $4.3 \%$ of their annual consumer spending. Id.

17. Stephen R. Latham, An Overview and Analysis of Legal and Policy Responses by the States, 24 J. LEGAL MED. 141, 143 (2003).

18. Robert L. Bartley, Thinking Things Over: Drug Prices: a Much-Needed Primer, WALL ST. J., July 22, 2002, at A15.

19. Geri Aston, Individual Market Tough for Many Insurance Buyers, AM. MED. NEWS, July 9/16, 2001, at 14; Randall R. Bovbjerg \& Frank C. Ullman, Health Insurance and Health Access, 22 J. LEGAL MED. 247, 247 (2001).

20. STUART O. SCHWEITZER, PHARMACEUTICAL ECONOMICS AND POLICY 93-97 (1997).

21. Out-of-Pocket Costs are a Substantial Barrier to Prescription Drug Compliance, HEALTH CARE NEWS (HarrisInteractive Inc., Rochester, N.Y.), Nov. 20, 2001, at 2 [hereinafter Out-of-Pocket Costs], available at http:/www.harrisinteractive.com/news/newsletters/ healthnews/HI_HealthCareNews2001 Vol1_iss32.pdf(on file with Indiana Health Law Review). This survey focused on noncompliance due to high co-payments; however, the overall finding of noncompliance with prescription medication due to high prices can be applied to the uninsured as well. 
choice of following a prescribed drug regime versus employing money for other needs, survey results indicate that noncompliance with the prescribed medication is common. A similar inclination is seen in the elderly. ${ }^{22}$ Serious health consequences often result when chronic diseases, prevalent in the aged population, are not treated according to the prescribed dosage. ${ }^{23}$

\section{B. United States Federal Health Care Programs}

Providing an avenue through which health care can be made available to all Americans has been a policy concern for several decades. The United States government established two national health insurance programs in 1965 in order to assist elderly and impoverished Americans to gain access to health care. ${ }^{24}$ Medicare covers the elderly, persons with certain qualifying disabilities, and people with End-Stage Renal Disease, ${ }^{25}$ while Medicaid acts to make health care available to the poor ${ }^{26}$ a class defined differently from state to state due to the states' ability to adopt independent need-based standards. ${ }^{27}$ When these federal insurance programs were instituted, they did not cover outpatient prescription drugs as part of the mandated benefits package. ${ }^{28}$ This has become increasingly problematic, especially among the aged population, as modern health care is relying more and more heavily on drug therapy. ${ }^{29}$ The increasing price of pharmaceutical drugs has only further exacerbated the situation.

22. KaISER Family Found., PRESCRIPTION DRUg TRENDS (2004), available at http://www.kff.org/rxdrugs/loader.cfm?url=/commonspot/security/getfile.cfm\&PageID=48305.

23. Out-of-Pocket Costs, supra note 21.

24. John Holahan, Financing Health CARE For tHE PoOR 1 (1975); Ctrs. for Medicare \& Medicaid Servs., Medicare Information Resource, at http://www.cms.hhs.gov/ medicare/default.asp (last modified Feb. 9, 2005) (on file with the Indiana Health Law Review).

25. Ctrs. for Medicare \& Medicaid Servs., Medicare Information Resource, at http://www.cms.hhs.gov/medicare/default.asp (last modified Feb. 9, 2005) (on file with the Indiana Health Law Review).

26. MichaEl S. SPARER, MEDICAID AND THE LIMITS OF STATE HEALTH REFORM 8 (1996); AleXander A. BoVe, JR., THE Medicaid PlanNIng HandBoOK 6 (1992). "[T] he Medicaid program is need based, providing benefits only to those patients who demonstrate a financial need ...." Id.

27. Conrad J. Barrington, Note and Comment, Pharmaceutical Research and Manufacturers of America v. Concannon and Maine's Prescription Drug Rebate Statute: A TwentyFirst Century Solution to the Medicaid Crisis, 23 WHITTIER L. REV. 1127, 1152 (2002); BOVE, supra note 26, at 6; HOLAHAN, supra note 24, at 3. Notably, states were allowed to set their own eligibility standards for their Medicaid program; they were to provide their own definition for the term "medically needy." Id.

28. Michael E. GluCK, NAT'LACAD. OF SOC. INS., MEDiCARE BRIEF No. 1, AMEdiCARE PRESCRIPTION DRUG BENEFIT (Apr. 1999), available at http://www.nasi.org/usr_doc/ medicare_brief_1.pdf.

29. See Earl P. Steinberg et al., Beyond Survey Data: A Claims-Based Analysis of Drug Use and Spending By the Elderly, HEALTH AFF., Mar.-Apr. 2000, at 198, 199; see also Sharon Levine et al., Kaiser Permanente's Prescription Drug Benefit, HEALTH AFF., Mar.-Apr. 2000, at 185 . 
In response to the bilateral problems of controlling drug prices and providing adequate coverage, Congress recently reformed Medicare's prescription drug policy to provide prescription drug benefits to some Medicare recipients. $^{30}$. Under this plan, which is scheduled to be fully implemented by January of 2006, low-income Medicare beneficiaries, including those who also receive Medicaid coverage in addition to Medicare, would receive additional coverage of their self-administered prescription drug costs. ${ }^{31}$ Critics of the reform state it does not provide the types of benefits seniors need and comes with a large price tag in a time of an already significant government deficit. ${ }^{32}$

While this program will assist the elderly in paying the high prices of prescription drugs, it does not provide similar benefits for the poor. "Although some prescription drug benefits are available through Medicaid, the federal mandate does not require such coverage."33 Despite the growing amounts of both state and federal funds provided to the Medicaid program and the millions of citizens who have received aid, significant numbers of the populace are excluded from coverage. ${ }^{34}$ Because of the differences among state eligibility requirements, a significant number of individuals who fall below the federal poverty level do not receive aid from Medicaid, and are unable to meet their prescription drug needs. ${ }^{35}$ Even if an individual is eligible for the Medicaid program, there are significant disparities in payments among states. ${ }^{36}$ Thus, a Medicaid recipient's status may depend upon the state in which he or she resides.

However, amidst this environment of rising costs, state governments are not necessarily acting unreasonably by enforcing limited Medicaid eligibility

30. Medicare Prescription Drug, Improvement, and Modernization Act of 2003, Pub. L. No. 108-173, 117 Stat. 2066 (2003).

31. Kaiser Family Found., Medicare Drug Benefit Calculator: Notes and Resources, at http://www.kff.org/medicare/rxdrugscalculator.cfm (revised Apr. 14, 2004) (on file with the Indiana Health Law Review).

32. Bush Signs Medicare Bill, CBSNEWS.COM, Dec. 8, 2003, at http://www.cbsnews.com/stories/2003/10/23/politics/main579645.shtml (last visited Apr. 17, 2005) (on file with the Indiana Health Law Review).

33. See Ctrs. for Medicare \& Medicaid Servs., Medicare Information Resource, at http://www.cms.hhs.gov/medicare/default.asp (last modified Feb. 9, 2005) (on file with the Indiana Health Law Review) (listing the certain services that must be offered to the categorically needy population in any State program). However, the Federal government has provided an incentive for states to include optional services such as prescription drug coverage under their state Medicaid plans by offering additional Federal funding if such a service is elected. Id.

34. SPARER, supra note 26, at 8; Frank J. Thompson, The Faces of Devolution, in MEdiCAID AND DEVOlUtion A VIEW From THE STATES 16-17 (Frank J. Thompson \& John J. Dilulio, Jr., eds., 1998).

35. Stephen B. Soumerai \& Dennis Ross-Degnan, Inadequate Prescription DrugCoverage for Medicare Enrollees-A Call to Action, 340 NEW ENG. J. MED. 722, 722-23 (1999); Thompson, supra note 34, at 16.

36. Thomas W. GRanNemann \& Mark V. Pauly, Controlling Medicaid Costs: FEDERALISM, COMPETITION, AND CHOICE 23 (1983). 
requirements and restricted optional coverage plans. ${ }^{37}$ States do not operate with unlimited funds and society is not often receptive to large tax increases. One possible solution to the disparate coverage problem may be to remove prescription drug benefits entirely from Medicare and Medicaid and vest all prescription drug authority in one comprehensive federal program that eliminates the states' discretion in defining need. While such a system would not eliminate the need for tax funding, it would allow the cost of the program to be spread more evenly across the nation.

\section{FACTORS CONTRIBUTING TO THE INCREASED COSTS OF PHARMACEUTICALS IN THE UNITED STATES}

The United States drug industry operates using free market pricing, but American drug prices are the highest in the world. ${ }^{38}$ Although much less than half of the prescription drug use worldwide can be attributed to Americans, Americans account for approximately half of the revenue of prescription drugs globally. ${ }^{39}$ There are several different factors contributing to this discrepancy.

Primarily, governments of industrialized nations, excluding the United States, impose price controls in order to keep the prices of pharmaceuticals low. ${ }^{40}$ By doing so, such governments decrease the value of the patents to their holders by limiting potential profit. Contrary to this majority system, "[t]he United States remains one of the only industrialized nations whose government has not imposed restrictions on pharmaceutical pricing." $" 41$

Due to free market pricing in the United States, there is little structural limitation on the amount drug manufacturers can charge for prescription drugs, save for the narrow controls enforced by health maintenance organizations (HMOs), pharmacy benefit mangers (PBMs), and government funded programs (Medicaid and Medicare). ${ }^{42}$ Critics view this as a sacrifice of the United States public health by the government supporting patent holder profits. $^{43}$

37. Barrington, supra note 27 , at 1153.

38. Tony Pugh, New Senate Bill to Allow Re-Importation of U.S.-Made Drugs from Canada, KNIGHT RIDDER WASHINGTON BUREAU, Oct. 30, 2003.

39. McClellan FDA Speech, supra note 1.

40. Talk of the Nation: Analysis: Obstacles to Reimporting Prescription Drugs from Abroad as a Way to Lower Pharmaceutical Drug Prices in the United States (NPR radio broadcast, Jan. 2, 2001) [hereinafter NPR Broadcast] (quoting Juan Williams).

41. Jerry Stanton, Comment, Lesson for the United States from Foreign Price Controls on Pharmaceuticals, 16 CONN. J. INT'L L. 149, 155 (2000).

42. Robert J.A. Basilio, Jr., The Battle for the People's Health and Wallets, BUSINESS WORLD, Jan. 5, 2001, at 25.

43. Letter from Ralph Nader and James Love to Tommy Thompson, Secretary, DHHS (Oct. 18, 2001), at http://www.cptech.org/ip/health/cl/cipro/nadethom10182001.html (last visited Apr. 17, 2005) (on file with the Indiana Health Law Review). But see David Olive, It's a Sad Sight to See Ottawa Ready to Give in to Bayer on Drug, TORONTO STAR, Oct. 23, 2001, at E03. 
Several other factors contribute to the elevated costs of pharmaceuticals in the United States besides the strength attributed to patent holders' rights. An escalation in the number of prescriptions, including unwarranted or improper drugs, which add to demand, is one such alternative source. ${ }^{44}$ Likewise, a general increase in drug prescriptions is contributing to the increase in the costs of such drugs. ${ }^{45}$ In addition, in the modern medical community there has been an increasing trend towards alternative means of treatment; namely, the substitution of prescription drugs in the place of medical procedures. ${ }^{46}$

Additionally, the United States requires all new drugs to obtain FDA approval prior to their placement in the market. The FDA's Center for Drug Evaluation and Research (CDER) was created to assure that all prescription and over-the-counter drugs are safe and effective; essentially, that the drug's benefits to society outweigh its potential risks. ${ }^{47}$ After the CDER determines a new drug is safe for consumer use, it continues to serve as a "consumer watchdog for the more than 10,000 drugs on the market to be sure they continue to meet the highest standards."48 Because the United States pharmaceutical companies must also satisfy the prerequisite of FDA approval to bring their new drugs to market, their expenses are increased all the more.

Another key contributing factor to the high price of pharmaceutical drugs in the United States is direct-to-consumer (DTC) advertising. Over the past decade, pharmaceutical companies have steadily increased their budgets for marketing, advertising and public relations. ${ }^{49}$ Accompanying the additional marketing expenses that pharmaceutical companies must account for in their drug pricing, DTC advertising has improved consumer awareness and placed pressure on physicians to prescribe the medications consumers request. $^{50}$ Advertising increases the costs consumers must cover when paying for their drugs and promotes the shift of the medical field from a service to a business. Such a shift naturally promotes the pharmaceutical company's attempt to maximize profits, therefore increasing product prices in accordance with increased demand.

In addition, consumer demand is relatively inelastic in relation to the price of prescription drugs because such drugs are often necessary to the

44. Mark H. Beers et al., Inappropriate Medication Prescribing in Skilled-Nursing Facilities, 117 ANNALS INTERNAL MED. 684 (1992).

45. Id.

46. QUESTIONS ABOUT MEDICINES, supra note 2.

47. DeP'T OF Health \& Human SERVS., FoOd \& DRUg AdMIN., PUb. No. FS 01-3, Just the Facts Improving Public Health: Promoting SAFE and EFFective DRUg Use (Aug. 2003) [hereinafter IMPROVING PUBLIC HEALTH], available at http://www.fda.gov/opacom/ factsheets/justthefacts/3cder.pdf; Michelle Meadows, The FDA's Drug Review Process: Ensuring Drugs Are Safe and Effective, FDA CONSUMER, July-Aug. 2003, available at http://www.fda.gov/fdac/features/2002/402_drug.html.

48. IMPROVING PUBLIC HEALTH, supra note 47.

49. Creech, supra note 2 , at 607.

50. Tamar V. Terizian, Notes and Comments, Direct-to-Consumer Prescription Drug Advertising, 25 AM. J. L. \& MED. 149, 157 (1999). 
person's ability to function. ${ }^{51}$ Often very few realistic drug substitutes exist and in certain cases, once prescription drug use has begun, it must be continued for a continuous period of time (e.g., anti-depressants). Moreover, numerous prescription drugs can be highly addictive, which can affect such a drug's demand as well. Where consumer demand is inelastic to price, pharmaceutical companies can charge more for a product than they could in a market where consumer demand fluctuates in response to drug price. ${ }^{52}$ With such a strong and stable consumer demand in addition to the limited governmental regulation in this area, pharmaceutical companies ultimately set the price of prescription drugs in the United States. ${ }^{53}$

\section{A. General Pricing Structure of Pharmaceutical Drugs in the United States}

As mentioned above, pharmaceutical manufacturers operate in a free market system and are able to price products in the United States at whatever level they wish, subject to minimal structural restrictions. ${ }^{54}$ Most of these firms are engaged in all phases necessary to bring a prescription drug to market, including the " $[R \& D]$ of different compounds, pushing new medicines through clinical trials, obtaining FDA approval, and the advertising and marketing of new drugs." ${ }^{\text {"55 }}$ Because these pharmaceutical manufacturers are involved in every aspect of bringing a drug to market, they have broad discretion in setting prices. ${ }^{56}$

R\&D expenses are the chief component behind the high costs of pharmaceutical drugs. To bring a new drug to market requires a substantial investment of time and resources. In addition, many of the costs associated with this process are sunk costs and therefore, largely unrecoverable once spent. ${ }^{57}$ Studies indicate that the average new drug costs $\$ 800$ million to develop and bring to market, ${ }^{58}$ a process which takes an average of fourteen years. ${ }^{59}$ While this high cost seems unreasonable at first glance, it is necessary to consider that "of every 5000 potential new drugs tested in animals, only five are

51. Patricia M. Danzon, Pharmaceutical Price Regulation: National Policies VERSUS GLOBAL INTERESTS 11 (1997).

52. Id.

53. Trudy Lieberman, Health Matters: Why Health Costs Sting Again, L.A. TIMES, Jan. 21,2002 , at $\mathrm{S} 1$.

54. Id.

55. Creech, supra note 2, at 598; Stanton, supra note 41, at 153.

56. Stanton, supra note 41 , at 155.

57. Id. ("Sunk costs are those incurred in preparing to bring a product to market....").

58. The Ballooning Price Tag, TuFTS E-NEwS, Dec. 4, 2001, at $\mathrm{http} / / / \mathrm{www}$. tufts.edu/communications/stories/120401BallooningCosts.htm (last visited Apr. 17, 2005 ) (on file with the Indiana Health Law Review).

59. William C. STEere, JR., THOUghts TOWARD a Medicare DRUg PlaN (Center for the Study of Am. Bus., CEO Series Issue No. 35, Sept. 1999), available at http://wc.wustl.edu/csab/CSAB $\% 20$ pubs-pdf $\% 20$ files/CEO $\% 20$ Series/ceo $35 \% 20$ medicare\%20drugs.pdf. 
promising enough to be tested in humans. Only one of those five is eventually approved for marketing." ${ }^{\circ 0}$ Logically, the revenues derived from successful medicines must not only cover the R\&D expenses involved in their own development, but also the R\&D costs of the unsuccessful medicines as well. ${ }^{61}$

Moreover, a pharmaceutical company must have the financial resources in place to develop and test thousands of compounds, knowing that very few of them will ever reach consumers and thereby potentially reap a profit. ${ }^{62}$ Thus, the profits from the successful drugs must be high enough to cover the R\&D expenses of the drugs that never reach the market. ${ }^{63}$ If drug manufacturers charged only the marginal cost of drug production - the cost of making each new pill-they would never recover their research costs, and the drug business would not be profitable. ${ }^{64}$

While critics concede developing and introducing a new drug into the market is an unquestionably expensive process, they have pointed out "that the billions of dollars spent on R\&D do not come out of the drug companies' pockets alone. ${ }^{165}$ In 1994, the United States federal government contributed fifty-five percent of the total amount spent on pharmaceutical drug R\&D. ${ }^{66}$ The National Institutes of Health (NIH) is the main source of most federally provided health care R\&D funds. ${ }^{67} \mathrm{NIH}$ funds have been used to develop one third of the most important drugs developed between 1965 and 1992. ${ }^{68}$

While federal funding does exist, pharmaceutical companies invest tremendous amounts of their own money on $R \& D$ as well. It is not uncommon for large pharmaceutical companies to invest several billion dollars annually in R\&D, over and above any federal aid they may receive.$^{69}$ If pharmaceutical

60. The Ballooning Price Tag, supra note 58; see also QUESTIONS ABOUT MEDICINES, supra note 2 , at 2 (providing graphical depictions of the R\&D costs and stating, "[t] cost of bringing one new medicine into the market is $\$ 500$ million ... [and] takes an average of twelve to fifteen years to discover and develop."). Note the $\$ 500$ million cost to bring to market was the statistic as of June of 2000 , which subsequently increased to $\$ 800$ million by December of 2001. Abbot Laboratories estimates it costs $\$ 900$ million to carry one drug all of the way through to market. JOHN LEONARD, ABBOTT LABORATORIES, NEW DEVELOPMENTS IN MEDICINE IN THE 21ST CENTURY (Oct. 2, 2003), available at http://abbott.com/citizenship/pdf/GPAI.pdf (on file with the Indiana Health Law Review).

61. QUESTIONS ABOUT MEDICINES, supra note 2.

62. Sarah E. Eurek, Hatch-Waxman Reform and Accelerated Market Entry of Generic Drugs: Is Faster Necessarily Better?, 2003 DUKE L. \& TECH. REV. 18 (2003).

63. Id.

64. Latham, supra note 17 , at 147.

65. Creech, supra note 2, at 601; Michael B. Moore, “Open Wide” (Your Pocketbook That Is!) - Call for the Establishment in the United States of a Prescription Drug Price Regulatory Agency, 1 Sw. J. L. \& TRADE AM. 149, 156 (1994).

66. Creech, supra note 2, at 601 .

67. Moore, supra note 65, at 157.

68. Id. at 156 .

69. On the high end, Pfizer, Inc. budgeted $\$ 7.1$ billion for R\&D in 2003. Pfizer Inc., How We Help: Research and Development, at http://www.pfizer.com/help/index.html (last visited Apr. 17, 2005) (on file with the Indiana Health Law Review). Additionally, Eli Lily spent $\$ 2.15$ billion on R\&D expenditures in 2002. ELI LILLY \& COMPANY, ANNUAL REPORT 2002 (2003), 
R\&D relied solely on subsidies from the federal government, the level of innovation currently seen in the United States pharmaceutical industry would be reduced, simply because the government could not afford to fund the current level of $R \& D$ expenses. However, as long as individual companies are spending their own money on R\&D, they will be at liberty to set their prices (absent government price caps or other limitations).

\section{B. Effects of Increased Pharmaceutical Prices in the United States}

Two main effects have resulted from the increased costs of United States pharmaceuticals. The high profits in the American drug industry create strong incentives for United States pharmaceutical companies to promote research of new drugs. Thus, high prices ensure that Americans will continue to promote the development of, and have access to, the most innovative drugs in the world. $^{70}$ Increased United States innovation is made apparent by the substantially longer wait international consumers must endure for access to new medicines as compared to American consumers. ${ }^{71}$

On the other hand, cutting edge medicines are of no use to consumers who cannot afford to purchase them. ${ }^{72}$ An increasing number of people in today's society are finding themselves unable to afford their prescriptions and are consequently being forced to seek similar pharmaceuticals from more affordable sources outside of the United States. ${ }^{73}$ While this problem is not limited to the elderly, the increase in the number of elderly people in the United States has added to the gravity of this problem. "Everyday millions of Americans . . . must choose between buying food or medication or between [sic] taking the fully prescribed dosage of medicine[,] or cutting their pills in half because a refill is too expensive." $" 74$ It is for this reason that American consumers are turning to the less regulated, cheaper foreign markets. When

http://lilly.com/investor/annual_report/lillyar2002financial.pdf(last visited Apr. 17, 2005)(on file with the Indiana Health Law Review). Abbott Laboratories reports it spends more than \$1 billion annually on R\&D. Abbott Laboratories, Corporate Overview, at http://abbott.com/ corporate/corporate_overview.html (last visited Apr. 17, 2005) (on file with the Indiana Health Law Review). Merck \& Co. reported spending just under $\$ 3.2$ billion in 2003 on R\&D which was a nineteen percent increase from their $2002 \mathrm{R} \& D$ expenses. MERCK \& Co. INC., ANNUAL REPORT 2003 (2004), http://www.merck.com/finance/annualreport/ar2003/financial section/merck2003_ar_financials.pdf (last visited Apr. 17, 2005) (on file with the Indiana $\overline{\text { Health Law Review). }}$

70. Creech, supra note 2, at 603.

71. NPR Broadcast, supra note 40.

72. Id. According to Rep. Sanders of Vermont, foreign countries value innovative drugs as well, but they also realize innovative drugs are only useful if their citizens are able to afford them. Id.

73. McClellan FDA Speech, supra note 1.

74. Creech, supra note 2, at 593 (citing 146 CONG. REC. S7193, (daily ed. July 19, 2000) (statement of Sen. Jeffords)). "In a study by the AARP, it was revealed that seven out of ten elderly Americans surveyed did not take the medicines prescribed to them because of the high costs." Id. (citing Moore, supra note 65, at 152 n.20). 
forced to choose between poor quality of life and the risk of possibly using counterfeit, contaminated, or ineffective foreign pharmaceuticals, these consumers are deciding to take their chances.

A balance must be struck between the consequences of increased prices of United States pharmaceuticals and the promotion of prescription drug innovation. While the United States asserts that it produces the world's leading drugs, there is no assurance that the people who need these drugs will be able to afford them. ${ }^{75}$ Advocates of the current pharmaceutical system could argue that the Supreme Court has held there is no constitutional right to health care, ${ }^{76}$ and therefore, there is no legal basis for prescription drug policy reform. On the other hand, it could be contended that a moral obligation exists to assist the disadvantaged. ${ }^{77}$

If viewed from a purely business perspective, United States pharmaceutical companies are merely creating a product and selling that product for a profit. Such companies are provided protection for their patent rights under the United States Constitution. ${ }^{78}$ While some believe companies have a moral obligation to make their drugs affordable, patent protection makes no distinction between products functioning as necessities versus luxuries. ${ }^{79}$

75. Creech, supra note 2, at 594.

76. DeShaney v. Winnebago County Dep't of Soc. Serv., 489 U.S. 189, 198-204 (1989) (holding the United States government is not obligated or liable to providing any affirmative social guarantees); Youngberg v. Romeo, 457 U.S. 307, 317 (1982); Cont'l Paper Bag Co. v. E. Paper Bag Co., 210 U.S. 405, 423 (1908) (holding the United States Constitution evinces no public policy that states a patent holder has to cede the use or benefit of his invention to the United States); Wideman v. Shallowford Cmty. Hosp., 826 F.2d 1030, 1031 (11th Cir. 1987).

77. While one could not be punished in the United States for a moral violation absent statutory codification of the specific offense, the majority of United States law and policy is grounded upon moral principles. Health care is an area where moral principles are weighing more and more heavily into policy decisions. The establishment of Medicare and Medicaid constitutes a clear expression of the American public's willingness to assist the disadvantaged, even at significant taxpayer expense. NORMAN DANIELS ET AL., BENCHMARKS OF FAIRNESS FOR HEALTH CARE REFORM 17 (1996); Thomas H. Murray, Genetics and the Moral Mission of Health Insurance, HASTINGS CTR. REP., Nov.-Dec. 1992, at 12, 16-17. Likewise, the Emergency Medical Treatment and Active Labor Act (EMTALA), 42 U.S.C. $\$ 1395 \mathrm{dd}$ (2004), is another example of American society's growing concern about moral fairness in the health care arena. Sharona Hoffman, Unmanaged Care: Towards Moral Fairness in Health Care Coverage, 78 IND. L. J. 659, 672-73 (2003). EMTALA requires hospitals to screen all patients who arrive in their emergency departments and stabilize their conditions regardless of the patient's ability to pay for those services. 42 U.S.C. $\$ 1395 \mathrm{dd}$ (a)-(b) (2004).

78. U.S. CoNST. art. I, $\S 8$, cl. 8. ("The Congress Shall have Power ... To promote the Progress of Science and useful Arts, by securing for limited Times to Authors and Inventors the exclusive Right to their respective Writings and Discoveries...."). It should be noted that the Constitution only provides for a monopoly over the patented product, it does not guarantee a profit from those patent rights.

79. 35 U.S.C. $\$ 101$ (2004) ("Whoever invents or discovers any new and useful process, machine, manufacture, or composition of matter, or any new and useful improvement thereof, may obtain a patent therefore, subject to the conditions and requirements of this title."); see also U.S. CoNST. art. I, $\S 8$, cl. 8. 


\section{FOREIGN PHARMACEUTICALS AND QUALITY ISSUES}

Because of the pricing discrepancy between United States and foreign pharmaceuticals, many Americans have turned to importing foreign manufactured drugs on their own. ${ }^{80}$ The potential savings are hardly trivial, given that an estimated " $\$ 90.7$ million a year could be saved if drugs for state employees and retired employees were bought across the border in Canada." 81 While American consumers claim this is the only way they can obtain the medicines they need, the safety of such a practice is questionable. Above all, foreign pharmaceuticals are not subject to regulation by the FDA, leaving much to chance in terms of the drugs' safety. ${ }^{82}$

One example of the risks posed by consumer importation of foreign drugs is provided by a 2001 Congressional study. The report found that the large amounts of drugs that had been re-imported into the United States have created health and safety risks to American consumers. ${ }^{83}$ The analysis focused primarily on American drugs that have been re-imported into the United States as American goods returned (AGRs). A major problem presented by reimported drugs lies with the improper handling and shipping by foreign countries, which introduces the possibility that the drugs may have become subpotent or adulterated. ${ }^{84}$ The Congressional report also revealed that reimportation of American drugs acted as a catalyst and cover for the foreign counterfeit drug market. ${ }^{85}$

When a pharmaceutical manufacturer is granted a patent for its new drug, the chemical structure of that patented drug, and frequently its chemical synthesis, can be found in either the patent application or in subsequent pharmaceutical literature. ${ }^{86}$ "Pharmaceutical peddlers are taking advantage of regulatory gaps to move millions of prescription drugs, including controlled

80. Jennifer Rak, Note, An Rx for Reform: A Medicare Prescription Drug Benefit, 12 HEALTH MATRIX 449, 449 (2002). at $\mathrm{A} 12$.

81. Monica Davey, Illinois Seeks Permission to Buy Drugs, N.Y. Times, Oct. 27, 2003,

82. Michelle Meadows, Imported Drugs Raise Safety Concerns, FDA CONSUMER, SeptOct. 2002, available at http://www.fda.gov/fdac/features/2002/502_import.html.

83. U.S. FoOD \& DRUG ADMIN., DEP'T HEALTH \& HUMAN SERVS., THE PRESCRIPTION DRUG MARKETING ACT REPORT TO CONGRESS 2 (June 2001) [hereinafter FDA PRESCRIPTION DRUG MARKETING ACT REPORT], available at http://www.fda.gov/oc/pdma/report2001/ 4228rpt.pdf.

84. Id. "Adulterated" is defined as a foodstuff containing "any poisonous or deleterious substance which may render it injurious to health ... [ [or] if it bears or contains any added poisonous or added deleterious substance . . . that is unsafe within the meaning of section 346 of this title." 21 U.S.C.A. \$ 342(a)(1)-(2) (2004). A foodstuff is also termed adulterated "if it has been prepared, packed, or held under unsanitary conditions whereby it may have become contaminated with filth, or whereby it may have been rendered injurious to health." Id.

85. FDA PRESCRIPTION DRUG MARKETING ACT REPORT, supra note 83.

86. Glenn Law, Note, Liability Under the Process Patent Amendments Act of 1988 for the Use of a Patented Process Outside the United States, 60 GEO. WASH. L. REV. 245, 247 (1991). 
substances, into the United States from Mexico, Canada, and elsewhere." With advancing technologies, the Internet providing easy access to information, and the ability to set up web ventures, counterfeiting pharmaceuticals has become an increasingly more prevalent and serious problem. ${ }^{88}$ Frequently, such counterfeiters do not even need access to the drug's chemical structure. ${ }^{89}$

Canadian drugs are not FDA regulated, providing no guarantee for their safety or efficacy. ${ }^{90}$ Therefore, when Americans travel to Canada to purchase cheaper pharmaceutical drugs they cannot be sure what they are buying. In addition, it is possible that such consumers could be unknowingly buying counterfeit medicines which could cause substantial harm to their health and livelihood. Thus, it is necessary for the United States to adopt a solution which caters to keeping drugs both affordable and safe.

\section{CANADIAN PATENT LAW}

Only forty years ago, the high costs of pharmaceutical drugs were causing problems in Canada similar to the dilemma facing the United States today. ${ }^{91}$ Canada was unable to promote the public welfare due to the extensive prices of pharmaceutical drugs. At that time, the prices of Canadian pharmaceutical drugs ranked among the highest in the world. ${ }^{92}$ In 1968, the Canadian government responded by enacting legislation that mandated the licensing of the patented drugs to generic manufacturers in order to have the effect of price control..$^{93}$

Nevertheless, twenty years following the 1968 licensing mandate, Parliament decided an unreserved compulsory system excessively encroached upon patent holders' rights, effectively diminishing incentive for innovation among researchers. ${ }^{94}$ While the compulsory licensing system was effective in decreasing the costs of pharmaceutical drugs to the public, it also decreased the monetary incentive for Canadian pharmaceutical manufacturers to invest in ongoing research in pursuit of novel drugs and, therefore, new patents.

Moreover, the United States was exerting pressure on Canada to reject the compulsory licensing system because it enabled individuals or corporations

87. McClellan FDA Speech, supra note 1.

88. Id.

89. Harrison, supra note 3, at 494.

90. Meadows, supra note 82.

91. Stanton, supra note 41, at 160.

92. Id.

93. Id. Such mandatory licensing of patented drugs to generic manufacturers is also referred to as compulsory licensing. Compulsory licensing was not a new concept in Canada, as their use of compulsory licensing can be seen as far back as the 1923 amendments to the Patent Act. Joel Lexchin, Pharmaceuticals, Patents, and Politics: Canada and Bill C-22, 23 INT'L J. HEALTH SERVS. 147, 148 (1993).

94. Patricia I. Carter, Federal Regulation of Pharmaceuticals in the United States and Canada, 21 LOY. L.A. INT'L \& COMP. L. J. 215, 242 (1999). 
to obtain a compulsory license from the Canadian Commissioner of Patents and use a United States patented process to manufacture a drug in Canada. ${ }^{95}$ In effect, the compulsory licensing system was facilitating the misappropriation of United States patents. The United States opposition to the Canadian licensing policy was so powerful and widespread that by October of 1985 , the United States Trade Representative complained in his annual report "that Canada's compulsory licensing policy was costing U.S. companies 'hundreds of millions of dollars." "96 Pharmaceutical companies in the United States were among the loudest voices heard in favor of using the United States' political force to encourage Canada to abandon its compulsory licensing system.

Influenced by interior concerns as well as political pressure from the United States, the Canadian Parliament implemented a compromise by granting the patent holder an exclusive term for at least seven years, after which mandatory licensing could be imposed..$^{97}$ However, such a compromise was not sufficient to satisfy the United States, and after extensive negotiation, the North American Free Trade Agreement (NAFTA) eliminated compulsory licensing altogether. ${ }^{98}$ In 1993, Canada implemented Bill C-91 and brought Canada into compliance with NAFTA's terms. ${ }^{99}$

Seven years prior to Bill C-91, the Canadian Parliament had established the Patented Medicine Prices Review Board (PMPRB) in anticipation of NAFTA's adoption. ${ }^{100}$ The PMPRB remains in effect today and serves as a review board possessing the power to compel disclosure of Canadian pharmaceutical manufacturers' confidential information concerning their drug pricing. ${ }^{101}$ After the PMPRB reviews the pricing information, it sets a wholesale price for the drug, which incorporates and accounts for a reasonable return on the patent holder's investment. ${ }^{102}$ This price serves as a cap which the pharmaceutical manufacturer cannot exceed. ${ }^{103}$

95. Harrison, supra note 3, at 505-24.

96. Id. at 512 (quoting David Crane, Drug Bill Concessions Seem Tied to Trade Talks, TORONTO STAR, Dec. 7, 1986, at B1).

97. Carter, supra note 94, at 242.

98. Harrison, supra note 3, at 511-24; Stanton, supra note 41, at 160. "Among other provisions, NAFTA mandates twenty year patent terms from the date of filing . . . and the elimination of compulsory licensing in all but a few limited circumstances, inapplicable here." Id.

99. Carter, supra note 94, at 243.

100. Id. at 245. In 1987, Bill C-22 created the PMPRB with the aspiration that the board could prevent drug manufacturers from taking advantage of their increased patent protection under NAFTA by charging higher prices. Patented Medicine Prices Review Board, Drug Patents and Drug Prices: The Role of the PMPRB, at http://www.pmprbcepmb.gc.ca/english/view.asp? $x=134 \&$ mid $=66$ (last visited Apr. 17, 2005) (on file with the Indiana Health Law Review).

101. Moore, supra note 65, at 156-66; see also Creech, supra note 2, at 615.

102. Moore, supra note 65, at 164 ; Stanton, supra note 41 , at n.100. "The PMPRB has no jurisdiction over retail prices." Id.

103. Creech, supra note 2, at 615. 
Initially the PMPRB was authorized to invalidate the drug's patent in Canada if the manufacturer failed to comply with the mandated information requests or pricing. ${ }^{104}$ However, in 1993, that invalidation power was stripped from the board and replaced by the power to merely impose financial penalties. ${ }^{105}$ Canada continues to use the PMPRB as the price control authority over pharmaceutical drugs, and it has been successful in keeping drug prices low. ${ }^{106}$

The evolution of Canadian patent law offers a valuable tool to the United States in drafting prescription drug reform. History illustrates the direct correlation between strong patent rights and increased innovation and vice versa. Likewise, the creation and success of the PMPRB shows that a review board can exist and determine reasonable market prices for pharmaceutical drugs. While following Canada's lead entirely may not be the most effective approach, ${ }^{107}$ it would be wise to consider Canada's experience in reshaping United States policy.

\section{UNITED STATES PATENT LAWS}

\section{A. Constitutional Grant of Power}

The power to patent an invention originates directly from the United States Constitution: "The Congress shall have power . . . to promote the Progress of Science and useful Arts, by securing for limited Times to Authors and Inventors the exclusive Right to their respective Writings and Discoveries ...."108 This reference to patent protection in the founding document of the United States evidences the long term commitment and historical importance attributed to patent rights. The main purpose of the patent system in the United States is exactly as the patent clause reads, to promote the progress and science of the useful arts. While inventors are rewarded via the monopoly bestowed upon them when they are granted a patent, the monopoly is merely a means to that end. ${ }^{109}$ The patent clause grants all governing authority to Congress. A textual reading of this clause suggests Congress has a type of all or nothing ability to grant patent rights: "Congress may either grant exclusive rights in the patented article, or grant no rights at all."

104. Moore, supra note 65 , at 163.

105. Id. at 164; PATENTED MEDS PRICES REVIEW BD., FIFTH ANNUAL REPORT FOR THE YEAR ENDED DEC. 31, 1992, at 3 (1993).

106. Moore, supra note 65, at 164.

107. Stanton, supra note 41, at 161-62 (noting that Canada is now a very small contributor to the "world's pharmaceutical pipeline."). Id. at 162. The significant differences between the two nations must be taken into account as well, including Canada's population is considerably smaller than that of the United States and is under a nationalized health care system.

108. U.S. CoNST. art. I, § 8, cl. 8.

109. See U.S. v. Mansonite Corp., 316 U.S. 265 (1942); see also Sinclair \& Carroll Co. v. Interchemical Corp., 325 U.S. 327 (1945).

110. Stanton, supra note 41 , at 150. 
Patent laws allow the patent holder to exclude people from using, providing or selling the invention throughout the United States in the absence of a license granted by the patent holder. ${ }^{111}$ In fact, the United States Supreme Court has construed the patent clause narrowly, indicating that "the language of complete monopoly has been employed."112 In the case of pharmaceutical drugs, patent rights bar competition from generic competitors for a period of twenty years from the filing of the patent. ${ }^{113}$ Pharmaceutical companies consider this term vital to their survival and to the continuous production of innovative drugs in order to combat the "free rider problem." because only one out of every ten drugs produced by pharmaceutical companies actually makes it to the market, the monopoly granted through their patent rights affords them the funds necessary to recoup their R\&D expenses of not only the drug that is being sold, but the other nine drugs which did not advance into the marketplace. ${ }^{115}$

\section{B. International Influence on United States Patent Law}

\section{Extraterritorial Effects of United States Patents}

While the Constitution and subsequent legislation confer the benefits of a monopoly upon the patent holder, these rights generally only have effect within the borders of the United States. Courts and analysts have often stated that patent rights do not have any effect abroad, absent some form of infringement within the United States. ${ }^{116}$ The Supreme Court has taken the position that, "[t]o the degree that the inventor needs protection in [foreign] markets . . . the wording of [the statute] . . reveals a congressional intent to

111. Deepsouth Packing Co., Inc. v. Laitram Corp., 406 U.S. 518 (1972)(interpreting what is now codified as 35 U.S.C. $\S 271$ (a)-(c), (e)(1), (f) (2004)).

112. Cont'l Paper Bag Co. v. E. Paper Bag Co., 210 U.S. 405, 423 (1908).

113. 35 U.S.C. $\$ 154(\mathrm{a})(2)(2005)$. It should be noted, however, that this twenty year term granted to the patent holder, on average, is reduced to a term of only ten to twelve years on the market free of generic competition due to the time it takes to put the drugs through clinical trials and to gain FDA approval. Patricia M. Danzon \& Li-Wei Chao, Does Regulation Drive Out Competition In Pharmaceutical Markets?, 43 J. L. \& Econ. 311, 312 (2000).

114. See Harrison, supra note 3, at 461-62. Pharmaceutical drugs are especially susceptible to this "free rider problem" because of the enormous discrepancy that exists between the R\&D costs of drug development and the manufacturing costs once the correct compound has been determined. Id. Once a foreign pharmaceutical company has obtained the drug's chemical structure (either through reverse engineering or similar method), it can then sell the drugs at a lower price than the United States' pharmaceutical companies because there is no R\&D overhead to recoup. Lehman, supra note 10, at 395. This situation has been termed the "free rider problem," and if allowed to continue unchecked, eventually these public goods will be underproduced. JANICE M. MUELLER, AN INTRODUCTION TO PATENT LAW 7 (2003).

115. QUESTIONS ABOUT MEDICINES, supra note 2.

116. Curtis A. Bradley, Territorial Intellectual Property Rights in an Age of Globalism, 37 VA. J. INT'L L. 505, 507-08 \& n.8 (1997) (demarcating the original scope of the direct infringement statute). 
have him seek it abroad through patents secured in countries where his goods are being used." 117

For this reason, American pharmaceutical companies cannot exert legal pressure upon Canadian drug manufacturers who duplicate their patented medicine (assuming the United States pharmaceutical companies have not obtained a Canadian patent). This is true as long as such drugs are not used, produced or sold in the United States. ${ }^{118}$ However, it is clearly a violation of patent rights when American citizens obtain such "generic" medicine from Canada and transport these drugs into the United States for their use. ${ }^{119}$

\section{The Doctrine of Exhaustion}

Nevertheless, a fundamental limitation on patent rights is the doctrine of exhaustion upon first sale. ${ }^{120}$ The doctrine of exhaustion has not been codified by the United States' Patent Act, however, it has been clearly established in common law. ${ }^{121}$ The courts have justified this doctrine by stressing that the patent $_{\text {purpose }}{ }^{122}$ is accomplished once the patent holder has received the benefit of the initial sale of the patented article. ${ }^{123}$

While Canadian drug manufacturers are selling generic versions of the United States patented drugs for discounted prices, American-made drugs are also available in Canada. Currently, it is not uncommon for individuals or companies to purchase American-made pharmaceuticals in Canada, where the drugs are cheaper, and subsequently re-import those drugs to be resold in the United States. ${ }^{124}$ These "re-imported" drugs are classified as parallel imports, which are goods sold or authorized for sale abroad by the United States patent holder, then subsequently re-imported and sold in the United States without

117. Deepsouth Packing Co., Inc. v. Laitram Corp., 406 U.S. 518, 531 (1972); see also HenRy G. Grabowski, Health Reform and Pharmaceutical InNOVATION 19, 14-15 (1994).

118. Deepsouth Packing Co., 406 U.S. at 526-27 (interpreting what is now codified as 35 U.S.C. $\$ 271$ (a)-(c), (e)(1), (f) (2004)).

119. 35 U.S.C. $\S 271$ (2004).

120. Darren E. Donnelly, Comment, Parallel Trade and International Harmonization of the Exhaustion of Rights Doctrine, 13 SANTA CLARA COMPUTER \& HIGH TECH. L.J. 445, 447 (1997). The doctrine of exhaustion or first sale provides that "once the patentee releases a patented product into the stream of commerce by selling or authorizing it to be sold to another, he exhausts his legal right to control that product." MARGRETH BARRETT, INTELLECTUAL PROPERTY: CASES AND MATERIALS 268-69 (2d ed. 2001). Therefore, the first purchaser, and those deriving title from him, may use and resell the product at will; see, e.g., Aro Mfg. Co. v. Convertible Top Replacement Co., 377 U.S. 476 (1964).

121. BARRETT, supra note 120, at 269.

122. The purpose for the Patent Act is to benefit inventors in order to create incentive to stimulate greater creative endeavors. See U.S. CONST. art. I, § 8, cl. 8.

123. BARRETT, supra note 120, at 274.

124. A. Bryan Baer, Note, Price Controls Through the Back Door: The Parallel Importation of Pharmaceuticals, 9 J. INTELL. PROP. L. 109, 109-10 (2001). 
the original patent holder's authorization. ${ }^{125}$ Once re-imported into the United States, the goods are in direct competition with the patent holder's goods. For that reason, international application of the doctrine of exhaustion is inherently capable of frustrating patent holders' attempts to maximize the value of their property rights. ${ }^{126}$

Two competing theories have emerged regarding the doctrine of exhaustion: the "international exhaustion" theory, providing the doctrine of exhaustion should apply regardless of the location where the goods are sold, and the "domestic exhaustion theory," providing the doctrine of exhaustion should be limited to patented articles manufactured and initially sold within the territory of the United States. ${ }^{127}$ International exhaustion is a controversial theory because it is contrary to the traditional notion that patent rights do not extend extraterritorially. ${ }^{128}$ Patent owners, especially in the pharmaceutical industry, argue that because patent rights are created by "domestic statutes of restricted territorial scope," the discounted sales of their patented products in a foreign market cannot exhaust their domestic patent rights. ${ }^{129}$ Moreover, the United States patent holders assert that because they are selling their drugs at a discount to foreign consumers, they have not received full value of their patented product. $^{130}$

The United States has not yet recognized the notion of international exhaustion with respect to patented items, although it has tolerated the theory in certain categories of copyrighted and trademarked goods. ${ }^{131}$ Moreover, the United States Patent Act expressly provides that the unauthorized importation of a patented invention is an actionable infringement. ${ }^{132}$ Finally, the United States Supreme Court enjoined the importation of a product covered by a United States patent but acquired abroad from an authorized source in its only decision regarding parallel imports of patented goods. ${ }^{133}$ Because the doctrine of exhaustion has been limited to domestic application, a state or the federal

125. Hillary A. Kremen, Note, Caveat Venditor: International Application of the First Sale Doctrine, 23 SYRACUSE J. INT'L L. \& COM. 161, 161-62 (1997).

126. David Perkins et al., Exhaustion of Intellectual Property Rights, in 2 PLI's FIFTH ANNUAL InSTITUTE FOR INTELLECTUAL PROPERTY LAW, at 41, 43, 45-46, 57 (PLI Patents, Copyrights, Trademarks and Literary Property Handbook Series No. 574, 1999).

127. BARRETT, supra note 120, at 274.

128. MUELLER, supra note 114, at 364.

129. Id. at 365 .

130. $I d$.

131. Id.; see Quality King Dist., Inc. v. L'Anza Res. Int'l, Inc., 523 U.S. 135 (1998) (copyrighted goods); K Mart Corp. v. Cartier, Inc., 486 U.S. 281 (1988) (trademarked goods).

132. See 35 U.S.C. $\$ 271$ (a) (2004) (including in the definition of patent infringement the "import[ation] into the United States" of any patented invention "without authority.").

133. Boesch v. Graff, 133 U.S. 697 (1890). Boesch's rejection of the international exhaustion doctrine was relied upon over one hundred years later in Jazz Photo Corp. v. Int'l Trade Comm'n, 264 F.3d 1094 (Fed. Cir. 2001), holding that for an accused infringer " $[\mathrm{t}] \mathrm{o}$ invoke the protection of the first sale doctrine, the authorized first sale must have occurred under the United States patent." Id. at 1105. 
government would be liable for infringement if they attempted to subsidize the re-importation of United States pharmaceuticals bought in Canada.

\section{The Fifth Amendment and Just Compensation}

A patent is a property right conveyed upon the patent holder as a reward for their innovation. ${ }^{134}$ Thus, its use is subject to all protections and limits afforded by the Fifth Amendment to the United States Constitution. The Fifth Amendment imparts, "[n]o person shall . . . be deprived of life, liberty, or property, without due process of law; nor shall private property be taken for public use, without just compensation."

In the proverbial bundle of rights which symbolize the rights characteristic of property, perhaps the most important stick is the power to exclude others. ${ }^{136}$ From a patent perspective, this is an essential right, as the substantial value of a patent is derived from the patent holder's ability to exclude potential competitors from manufacturing the patented product, resulting in the patent holder's domination of a niche in the industry. A patent holder can bring an action directly against the alleged infringer if that infringer is a member of the private sector, however, when the infringement is one of government action, the law is more complicated.

Federal law waives the United States government's immunity from private suit, while concurrently allowing the federal government or its contractors to legally infringe upon a valid patent for the government's use. ${ }^{137}$ Where the government infringes upon a patent on section 1498 grounds, this is a taking under eminent domain, ${ }^{138}$ which entitles such a patent holder to "reasonable and entire compensation for such use and manufacture."

134. See Markman v. Westview Instruments, Inc., 52 F.3d 967, 985 (Fed. Cir. 1995).

135. U.S. CoNST. amend. V.

136. Stanton, supra note 41, at 151 ; see In re Etter, 756 F.2d 852, 859 (Fed. Cir. 1985).

137. 28 U.S.C. $\$ 1498$ (2004); Daniel R. Cahoy, Treating the Legal Side Effects of Cipro: A Reevaluation of Compensation Rules for Government Takings of Patent Rights, 40 AM. Bus. L. J. 125, 139-40 (2002). In 1910 a House of Representatives Report accompanied the bill which became the predecessor statute to section 1498 . Id. at 140 n.61. The report stated, "[o]ur only purpose is ... to give the court in patent cases, in addition to the jurisdiction it now has in matters of contract, jurisdiction in cases of tort." Id.

138. See Leesona Corp. v. United States, 599 F.2d 958 (Ct. Cl. 1979); Cahoy, supra note 137, at 142. The Founding Fathers, concerned with the possibility of government tyranny, placed an important limitation upon the government's power of eminent domain: "a requirement that fair compensation be given by the government for any taking of property." Id.

139. 28 U.S.C. $\S 1498$ (a) (2004).

Whenever an invention described in and covered by a patent of the United States is used or manufactured by or for the United States without license of the owner thereof or lawful right to use or manufacture the same, the owner's remedy shall be by action against the United States in the United States Court of Federal Claims for the recovery of his reasonable and entire compensation for such use and manufacture.... 
patent taking under eminent domain can be likened to the government offering fair market value for a residence in the projected path of a new highway system. While the government is authorized to take the house, compensation must be made to the owners at a fair and just price. Likewise, just as a homeowner is prohibited from refusing to sell their residence, section 1498 precludes a patent holder from asserting an injunction against the United States to prohibit use of his patent. ${ }^{140}$ However, this statute does not eliminate the patent holder's Fifth Amendment right to just and reasonable compensation. "[I]f taking the property is truly important for the good of the state, the state (and the taxpayers who support it) should be willing to pay a fair and just price for it." ${ }^{141}$ Determining that fair and just price introduces another complication into the Fifth Amendment scheme. When pharmaceutical companies price their drugs they take into account that the profits from the successful drug must cover the R\&D costs of the other drugs that did not reach the market. ${ }^{142}$ The exact R\&D costs of the unsuccessful drugs could also be a question of accounting and the length of time that the pharmaceutical companies choose to spread their loss. Future profits and loss spreading make it difficult to determine exactly what fair and just compensation would be in any given situation.

\section{Compulsory Licensing as a Taking}

In the patent context, a taking by the United States government has traditionally been in the form of a "compulsory compensable license in the patent." 143 Just compensation has usually been calculated as "reasonable royalty" for the use of that license, or when that cannot be established-as often is the case-another method of calculating the value of the appropriated patent will be employed. ${ }^{144}$ Such government appropriations of patents have been relatively rare in the past, but with the evolving worldwide epidemicsHIV/AIDS, Trachoma, Avian influenza, etc.-and the increasing threat of bioterrorism in the United States, as evidenced by the October 2001 anthrax scare, actions under section 1498 have become increasingly ominous. ${ }^{145}$ Further, if

140. Cahoy, supra note 137, at 152; see, e.g., Motorola, Inc. v. United States, 729 F.2d $765,768 \mathrm{n} .3$ (Fed. Cir. 1984) (stating "injunctive relief under 35 U.S.C. $\S 283$ is not available to a patent owner in a $\S 1498$ action."); see also Leesona Corp., 599 F.2d at 968 "The injunctive relief of 35 U.S.C. $\$ 283$ could not be awarded, of course, since this court lacks the power to grant such relief." Id.

141. Cahoy, supra note 137, at 142.

142. Eurek, supra note 62, at 18.

143. Leesona Corp., 599 F.2d at 968.

144. Id.

145. John A. Harrelson, Note, TRIPS, Pharmaceutical Patents, and the HIV/AIDS Crisis: Finding the Proper Balance Between Intellectual Property Rights and Compassion, 7 WIDENER L. SYMP. J. 175, 175 (2001); Cahoy, supra note 137, at 125-26. In October of 2001, the United States experienced a major threat to its national security as a result of bioterrorism. The designed release and distribution of Bacillus anthracis ("anthrax") throughout the country created a widespread panic among the American public. Government discussion quickly moved 
section 1498 actions are employed by the government and a compulsory license is issued, the entire process could cost the government more, as the patent holding company must be compensated, and payment would be rendered to the generic pharmaceutical manufacturer that actually made the drug. ${ }^{146}$

Pharmaceutical companies often strongly protest compulsory licensing, even when they are awarded what the courts determine to be reasonable and full compensation. One reason for this is that "reasonable compensation" is largely ambiguous on its face and the reasonableness of a damage award is likely to depend on whether the pharmaceutical companies or the courts are making the judgment. ${ }^{147}$ Additionally, "a rule creating a disadvantaged compensation scheme for government appropriated patents would be perceived as weakening the intellectual property right for affected arts."148 It would be reasonable to expect to see a reduction in investment in research areas more apt to be subject to governmental takings if such a government action became exceedingly widespread. ${ }^{149}$ Companies would simply not be willing to invest the necessary capital on innovative research if the capability to make future profits was likely to be stripped, only to be replaced by "reasonable compensation" to be decided by a court.

While the reasons pharmaceutical companies may be opposed to compulsory licensing are somewhat obvious, the United States government also has an interest in refraining from the appropriation of its patents. First, the United States has a strong interest in encouraging innovative research in the area of pharmaceutical drugs. It is perceivable that Canada's model of price regulation through compulsory licensing does not provide the incentive necessary to maintain the level of pharmaceutical innovation currently seen in the United States. ${ }^{150}$ Adequate incentives must be present in order for the United States to remain among the countries with the highest levels of pharmaceutical innovation in the world. Therefore, investment in research and development of new drugs is vital.

A second incentive, and perhaps a less obvious one, is that the government may be hesitant to employ compulsory licensing because of its possible effect on international relations. The United States does not want to under-

to the compulsory licensing of the patent rights to ciprofloxacin, the only antibiotic approved by the FDA for treatment of inhalation anthrax, in order to decrease the cost of the drug by allowing a generic form to be produced by companies other than the original patent holder (the German pharmaceutical company, Bayer, A.G.). Id. at 125-28. However, before the government "overrode" the ciprofloxacin patent, Bayer promised to increase its production of the drug three-fold along with considerably reducing the price it charged the U.S. government. Id. at 127.

146. Id. at 171-72.

147. See, e.g., Crozier v. Fried. Krupp Aktiengesell-Schaft, 224 U.S. 290, 307 (1912).

148. Cahoy, supra note 137 , at 170.

149. Id.

150. Stanton, supra note 41 , at $162,167-68$. 
mine its negotiating position with developing countries over whether the Agreement on Trade-Related Aspects of Intellectual Property Rights (the "TRIPS Agreement" or "TRIPS") allows these countries to override United States patents. ${ }^{151}$ Developing countries have a strong interest in being able to obtain the innovative drugs which combat diseases such as AIDS, but the majority of these drugs are manufactured by United States pharmaceutical companies. Thus, overriding United States patents would successfully enable them to effectively address HIV/AIDS or similar pandemics. ${ }^{152}$ Developed countries maintain that these drugs are only available because of the existence of a high level of patent protection, which allows pharmaceutical companies to be comfortable with investing the billions of dollars necessary for continuing R\&D. ${ }^{153}$

\section{Potential SOLUTIONS}

American consumers pay the highest prices in the world for pharmaceutical drugs. In exchange for this financial burden, Americans enjoy increased access to the most innovative drugs, assuming their budgets allow. Development of new and innovative drugs is dependent upon the strength of patent laws, or analogously, the promise of future profits. Observing the evolution of the Canadian patent system provides reinforcement for this theory. After the Canadian government weakened their patent laws-thereby depressing the possibility of profits for the drug companies - Canadian pharmaceutical innovation decreased.

Consumers may tend to under-value the possible benefits of a not-yetdeveloped drug, since the unknown benefits would be pitted against the likelihood of high prices at the pharmacy. American consumers must decide if they are willing to sacrifice the potential for future developments of new life-saving drugs for smaller bills in the short-term. Furthermore, if a high level of innovation is determined to be the ultimate goal, action should be taken by the federal government to create a solution for the class of individuals currently unable to pay for prescription drugs.

While permitting the importation of pharmaceutical drugs from Canada may seem to be the straightforward and logical solution to the United States' increasing prescription drugs prices, in the long run it could have a severe and negative impact on American public health and the United States pharmaceutical industry. Because such drugs are not FDA regulated, the quality and effectiveness of foreign drugs cannot be guaranteed. Moreover, allowing foreign pharmaceutical drugs into the United States market, especially through

151. James Thuo Gathii, The Legal Status of the Doha Declaration on TRIPS and Public Health Under the Vienna Convention on the Law of Treaties, 15 HARV. J. L. \& TECH 291, 29495 (2002).

152. Id.

153. Id. at 294. 
internet purchasing schemes, amplifies the opportunity for counterfeit drugs to reach American consumers. Although increasing FDA funding may enable that agency to regulate foreign pharmaceutical imports, supplying FDA officials with the financing required to detect and police these imports would likely compel either large tax increases or a significant increase in the United States deficit. For these reasons additional methods should be explored to increase the affordability of United States pharmaceuticals to the American public, and our borders should be closed to pharmaceutical drug imports.

\section{A. Patent Infringement}

As a matter of law, if a state or federal government were to import pharmaceutical drugs into the United States that were identical or substantially similar to those under a United States patent, the United States patent holder would have a valid claim of infringement and would entitle it to just and fair compensation. Under the domestic exhaustion principle adopted by the Supreme Court, even American-made drugs sold abroad and subsequently resold in the United States without the original patent holder's authorization would be considered an infringement. In either of these cases, United States companies holding pharmaceutical patents could obtain an injunction against the infringer.

Section 1498 allows the federal government to prevent the patent holder from asserting an injunction against the United States. However, reasonable and entire compensation must be made for the use of the patent. The determination of what is reasonable and entire compensation for a pharmaceutical drug is a problematic and controversial process. If the government were to compulsory license a patented drug, determining its fair value would entail projecting the amount of future profits necessary to cover the R\&D of not only the successful drug, but also the sunk costs of the unsuccessful drugs that never were approved for the market. If the United States government were to make a practice out of compulsory licensing, this would not only weaken United States pharmaceutical patents, but it would also undermine the United States' international stance that other countries must respect United States patents. Either consequence would effectively decrease incentive for pharmaceutical companies to invest the sizeable amounts of money necessary for innovation. While non-FDA regulated pharmaceuticals may not be the answer, a solution must be found, as the rising prices of pharmaceutical drugs in America is leaving significant amount of the population without access to pharmaceutical drugs.

\section{B. Alternative Solution: National Prescription Drug Aid Program}

The establishment of a centralized federal agency with limited and exclusive regulatory power over prescription drug prices may be the answer. If this new federal program were employed, all prescription drug authority could be 
removed from Medicaid and Medicare, eliminating any discrepancies between programs and providing equal protection for all who meet the eligibility requirements. The key to such a program would be achieving the most efficient need-based eligibility standard. Such eligibility standards should expand upon those currently utilized by the Medicaid and Medicare programs in order to encompass the largest percentage of the uninsured population. Achieving this standard has the potential to save the government money in the long term, as providing preventative care through prescription drugs is often less expensive than providing emergency treatment. ${ }^{154}$ Further research is needed to determine the income level at which an individual is likely to purchase pharmaceutical drugs, so as to achieve the appropriate eligibility standard.

Regardless of the solution adopted to combat the affordability problem of United States pharmaceuticals, it is highly likely additional funding will be necessary. If this prescription drug pricing agency were adopted, because of the program's federal nature, taxes could be spread throughout the entire United States population thereby reducing the impact on the individual. Investing federal taxes into the proposed program would be considerably more efficient than funding the regulation of foreign pharmaceutical imports which would create new problems and additional costs in long run. Additionally, because the existing Medicare and Medicaid programs currently receive funding for their limited prescription drug benefit programs, a proportionate amount of those subsidies could be shifted to the new prescription drug agency. Likewise, because the two existing programs' pharmaceutical drug benefits would effectively be excised and consolidated into one separate program, this would produce a more efficient system. Theoretically, these factors could decrease the amount of additional taxation necessary to support the new agency.

\section{Agency Price Determination}

The proposed federal program would operate in a similar fashion to the recent Medicare Prescription Drug Benefit Act. The new agency would purchase the drugs from United States pharmaceutical companies at a discounted price. Such price would be set by a review board similar to the PMPRB utilized in Canada.

154. Janet O'Keeffe, The Right to Health Care and Health Care Reform, in HEALTHCARE REFORM: A HUMAN RIGHTS APPROACH 35, 40-41 (Audrey R. Chapman, ed., 1994). Currently, the poor and uninsured must be admitted for expensive institutionalized care when their health has deteriorated enough that they require emergency treatment. Id. Generally the costs associated with such emergency treatment greatly exceed the costs of the forgone preventative treatment. Id. The discrepancy between these two costs is passed along to taxpayers by increased medical bills to all of society. $I d$. 
This pricing board's authority would be limited to the federal program and would not extend to mandating price caps for the regular market. In contrast to the Canadian PMPRB, this pricing review board would not automatically be authorized to compel disclosure of United States pharmaceutical manufacturers' confidential drug pricing information, given that it is unlikely United States pharmaceutical companies would cooperate with such a scheme. The review board's main function would be to assess the global market for the pricing of equivalent medicines and negotiate with the United States pharmaceutical companies to set a price falling somewhere in between the United States and global market prices. Only in the event that a United States pharmaceutical company refuses to negotiate or agree upon a reasonable ${ }^{155}$ price may the review board be afforded the power to compel confidential pricing information from the uncooperative company. The agency price will then be set according to the review board's evaluation of the pricing information. All compelled pricing information should be kept strictly confidential.

The new agency would then purchase the pharmaceutical drugs directly from the manufacturers at the price agreed upon. Eligible participants of the program could then purchase these drugs from the agency at the average global market price. For example, if the review board found the average global price of a certain prescription drug was $\$ 3.00$ per pill and the price for the similar pill in the United States was $\$ 10.00$, the review board and the United States patent holder would negotiate and set an agency price at $\$ 7.00$ per pill. The agency would then purchase these pills from the pharmaceutical company at $\$ 7.00$ per pill and subsequently make the drugs available to eligible individuals at $\$ 3.00$ per pill. In this way, the agency would have to consume only a percentage of the pharmaceutical drug costs, thereby lessening the tax burden Americans must bear.

This program would provide a means for elderly and impoverished Americans to have access to affordable and FDA regulated pharmaceutical drugs. There is no reason this program should directly impact the market prices of United States pharmaceuticals. Any drugs sold to the new agency would be above and beyond the companies' current sales, thereby extending the reach of pharmaceutical companies to a sector of the market previously unable to afford their product. Due to the marginal costs associated with increased pill production, it seems the patent holders themselves can take advantage of the "free rider problem" while still increasing their profit margin since increasing production is not financially inhibitory. Therefore, United States pharmaceutical companies could continue to cover their R\&D costs and innovation would be spared. Moreover, because the companies are being com-

155. The term "reasonable" should be defined prior to the adoption of the agency. A suggestion for the reasonable standard would be to set the price as a set percentage above the global market price, however, the precise definition can be negotiated for when the plan is enacted. 
pensated for their products, this solution avoids any Fifth Amendment quandaries.

While the additional taxation necessary to fund the agency would indirectly increase the burden of pharmaceutical drug prices on more wealthy Americans, this trend is not uncommon in the United States. While critics may attack this program as throwing the weight of the problem onto the backs of the affluent, this argument ignores the underlying predicament entirely. The problems associated with the current system of pharmaceutical drug pricing in the United States are not going to disappear without the implementation of a solution that impacts the public as a whole. The establishment of this new agency offers a solution that both meets the needs of Americans who are presently unable to afford pharmaceutical drugs, and protects United States pharmaceutical innovation and the safety of the United States pharmaceutical drug supply.

\section{Closing the Borders}

Merely establishing a centralized agency to help combat the affordability problem of United States pharmaceutical drugs will not resolve the issue alone. Making American pharmaceuticals affordable for indigent individuals will be a significant step towards decreasing American consumer incentive to seek drugs outside of the United States. However, that incentive will remain for the people who do not qualify for aid. Consumers cannot be relied upon to entirely discontinue seeking out less expensive foreign drugs without the possibility of repercussions in place. The most efficient approach to securing the safety of the American drug supply is to close the borders entirely to foreign drug imports. It would be unrealistic to expect an embargo on the importation of pharmaceuticals to prevent all foreign drugs from entering the market. However, making the act of importation illegal may inadvertently increase the price of foreign pharmaceuticals, thereby lessening their appeal.

Additional funding will also be required to implement the stringent importation prohibition. However, it is not necessary that such funding be derived from tax dollars. The United States pharmaceutical companies have a substantial interest in closing the borders to foreign pharmaceuticals, as the competition weakens their market foothold. Therefore, it would be in the United States pharmaceutical companies' best interest to fund the FDA's implementation of a prescription drug import embargo.

If adequate funding was not made available merely by placing the security control in the hands of these large companies, several avenues could be explored to increase their motivation. For example, United States pharmaceutical companies have large budgets reserved for DTC advertising. If such companies complained of the burden associated with their border responsibilities, the federal government could simply prohibit DTC advertising for pharmaceutical drugs and those funds could then be devoted to securing the borders. Securing the safety of the American pharmaceutical drug supply is 
more essential to promoting the public health than marketing prescription drugs to vulnerable consumers in search of the "magic pill."

\section{CONCLUSION}

Clearly, the pharmaceutical pricing situation cannot continue as it exists today. The importation of foreign pharmaceuticals violates federal law, infringes upon patent rights, weakens United States patent protection afforded by the Constitution, and creates an imminent threat to the public health. Because of the number of competing interests, the most effective solution is one of compromise. The creation of a central federal agency may not be the optimal solution, however, it illustrates that an answer can be found in a middle ground. The competing and intertwined interests complicate the overall issue, but also provide valuable bargaining power for compromise. If the optimal balance is struck, it will be possible to make prescription drugs more affordable to the elderly and the uninsured while protecting drug innovation and quality. 